\title{
Estimating Optimal Level of Taxation for Growth Maximization in Asia
}

\author{
Jeeban Amgain \\ Correspondence: Jeeban Amgain, Graduate School of Economics, Kobe University, Kobe City, Japan. \\ Received: February 10, 2017 \\ doi:10.11114/aef.v4i3.2288 \\ Accepted: March 5, 2017 \\ Available online: March 19, 2017 \\ URL: https://doi.org/10.11114/aef.v4i3.2288
}

\begin{abstract}
What level of tax revenue in GDP is suitable for a country to maximize the growth rate in Asia? To address this question, this paper estimates the optimal size of taxes which maximizes growth rate, using Scully and quadratic models, from the unbalanced panel data of 32 Asian countries. Both methods approve that tax revenue around 18 percent of GDP maximizes the growth rate. However, quadratic model provides more consistent result than the Scully model. Most importantly, the findings clearly show the existence of inverse U-shaped relationship between taxes and growth.
\end{abstract}

Keywords: taxation, optimal size, growth maximization, scully model

\section{Introduction}

Taxation has been the main source of government revenue across the world except some oil based economies. It also plays a great role in capital formation and output growth, thereby providing a sustainable source of public investment. A certain level of tax revenue in GDP is required for maintaining fiscal sustainability and is also considered to be an important indicator to meet the standard of the developed nation. However, the evidence on tax-growth relationship provides quite disappointing results. Some recent evidence in this regard reveals that this relationship is consistently negative (Gemmell and $\mathrm{Au}, 2012$ ). Although theoretical developments in endogenous growth model clearly explain the optimality condition of the government size, practical assessment in measuring the exact size is quite difficult.

From the perspective of optimal taxation, both higher and lower sizes of tax revenues are not supportive to higher growth. Higher taxation, in one hand, discourages the investment and labor supply, which in turn reduces growth. On the other hand, lower taxation creates a resource gap which significantly hampers public investments even in essential areas where private sector does not pay special care. This leads to a outstanding debt stock if deficit finance is used to fund public spending, causing uncertainty in the future investment and targeted growth. Hence, determining the suitable level of tax revenue in GDP is the major concern of the economists to resolve fiscal issues and ensure higher growth.

A body of literature shows that adapting optimal tax policy leads to a higher growth (for e.g. Jones and Manuelli, 1993; King and Rebelo, 1990). But the major question is what size of tax revenue is optimally suitable for a country to maximize growth. Barro (1990) developed a model showing growth-maximizing condition of lump sum taxation under the assumption of balanced budget. His model indicates that maximum growth is achieved when the size of government equals to the share it would hold when public services were delivered competitively as an input of private sector. Although his model indicates inverse U-shaped relationship between taxes and growth, the model has not been popular to quantify growth-maximizing tax level. But Scully $(1995,1996)$ developed a model to estimate optimal tax burden rate showing that tax-growth relationship is inverse U-shaped. While some recent studies use quadratic method to find the optimal size of tax revenue. They clearly show that relationship is positive up to a certain level and starts to become negative after crossing that level.

Unlike many traditional approaches which depict linear relationship between taxes and growth, non linear approach showing inverse U-shape is highly recognized as it admits both positive and negative behaviour of taxation. However, a majority of the conclusions in this regard are drawn from developed countries and linear regression results. Only the linear and negative tax-growth relationship is not sufficient to provide a meaningful explanation for the required level of tax revenue. Hence, this research tries to estimate the growth-maximizing tax burden rate using the data from Asian countries which mostly covers developing countries.

\section{Literature Review}

The emergence of endogenous growth theory in the early 1990s gave an insight through which the long-run effect of taxation can be examined. Some previous theories regarding the optimal taxation are far from the reality. There exists a 
large gap between theory and tax policy; the implication of the theoretical prescriptions are rare in practice (Mankiw, Weinzierl and Yagan, 2009). Barro (1990) advanced the endogenous model showing inverted U-shape relationship between taxation and growth. Subsequently, Armey (1995) and Rahn and Fox (1996) and Scully (1996) developed theoretical literature on optimal size of the government, and particularly Scully tested empirically the growth-maximizing level of taxation showing the existence of inverse U-shaped tax-growth relationship.

A large body of recent empirical literature shows that higher size of taxation hampers economic growth (for e.g. see McBride, 2012). The studies which yield inconclusive results of taxation are also equally large (e.g. Easterly and Rebelo, 1996; Gale, Krupkin, and Rueben, 2015). Only a few studies show a positive relationship between taxation and growth. Most of empirical literature which follows linear regression technique shows the negative impact of taxation on growth. However, some studies which are based on threshold and quadratic models depict a positive relationship up to some point and negative after this. Among these, only few literature talks about the optimal size of taxation which maximizes growth. Scully model is one of the most convincing and practical method of finding optimal size of taxation for growth maximization although some critics show disagreement on the reliability of this model.

Scully himself conducted a series of studies to find the optimal tax size and found that around 20 percent of GDP is suitable for the higher growth. Scully (1991) used quadratic method by taking the data from 103 countries and observed that 19.3 percent of GDP is the growth-maximizing tax rate. ${ }^{1}$ In 1995, Scully surveyed the data of USA (1949 1989), and concluded that growth-maximizing tax rate is between 21.5 and 22.9 percent of GNP. Similarly, Scully (2003) used two models- Barro and Scully. He found that growth-maximizing tax rate for the USA is 25.1 and 19.3 percent, respectively. Scully (2006) again surveyed the data of USA (1929 2004), by using his own method developed in 1996, and found that the optimal tax rate for the highest growth is 23 percent of GDP.

Following the Scully method, some other studies have tried to calculate the optimal tax rate, however, the optimal size observed across the studies is not uniform. Chao and Grubel (1998) applied Scully method for Canadian data and explored that the optimal size of taxes for growth maximization in Canada is 34 percent of national income. Keho (2010) used the data of Cote d'Ivorie (1960 to 2006) and observed that optimal tax rate is between 22.1 22.3 percent of GDP. Similarly, Abdullaev and Konya (2014) used the same method for Uzbekistan (1996 2011) and found that the optimal tax rate is 22 percent of GDP for prior to 2001 and 31.25 percent for post 2001. Davidsson (2012) slightly modified the Scully (1996) method and applied in randomly selected 12 countries for the period of 1982 2012 and found a low tax rate of 11.1 percent of GDP. Similarly, a study conducted by Saibu (2015), using the data of South Africa and Nigeria, found that the growth-maximizing tax rate for South Africa is 15 percent and Nigeria is 30 percent of GDP. Likewise, Husnain, Haider and Salman (2015) used Scully model, with the inclusion of deficit term, for 4 South Asian countries and found that $13.78 \%$ is the growth-maximizing tax rate. A brief review of related literature has been summarized in Appendix 2.

Although Scully model is popular, the results provided by this model for optimal tax rate are inconsistent, with the large variation. Almost all studies are based on the time series data. The researches which cover low-income countries in Asia are very rare. Hence, this study tries to find the optimal level of taxation which maximizes growth in Asian countries.

\section{Methodology}

Following Scully (1996), we develop the model which establishs the relationship between taxation and economic growth. There exist two sectors in the economy: government sector and private sector. Government provides the public goods by labor and capital, which are solely financed through taxation. The untaxed part of the national income is used by the private sector to produce private goods. To produce the final goods, both government and private sources are used. Hence, total output is the sum of the output of the two sectors.

The production function in the Cobb-Douglas form is:

$$
Y_{\text {it }}=\beta_{0}\left(G_{\text {it }-1}\right)^{\beta_{1}}\left[(1-\tau) Y_{\text {it }-1}\right]^{\beta_{2}}
$$

Where $\mathrm{Y}$ is the output, $\mathrm{G}$ is the government spending for public good, $\mathbf{\tau}$ is the lump sup tax rate for the corresponding period and $t$ is the time period.

We assume that the government budget is balanced. Hence, the government budget constraint is:

$$
G_{\text {it }}=\tau Y_{\text {it }}
$$

where $\tau$ is the tax-GDP ratio. Here we simply say tax rate.

From 1 and 2, we can write:

$$
\mathrm{Y}_{\mathrm{it}}=\beta_{0}\left(\tau Y_{\mathrm{it}-1}\right)^{\beta_{1}}\left[(1-\tau) Y_{\mathrm{it}-1}\right]^{\beta_{2}}
$$

\footnotetext{
${ }^{1}$ Tax rate in this paper refers to the proportion of tax revenue in GDP.
} 
Growth rate is defined by:

$$
\mathrm{Y}_{\mathrm{it}} / Y_{\mathrm{it}-1}=1+\mathrm{g}
$$

Hence, dividing both sides by $Y_{\text {it- } 1}$,

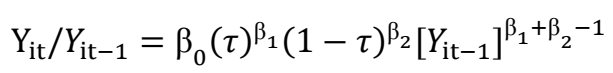

or

$$
1+\mathrm{g}=\beta_{0}(\tau)^{\beta_{1}}(1-\tau)^{\beta_{2}}\left[Y_{\mathrm{it}-1}\right]^{\beta_{1}+\beta_{2}-1}
$$

Growth-maximizing tax rate $\mathbf{\tau}$ is obtained by differentiating equation (3) with respect to $\boldsymbol{\tau}$ and setting to zero. i.e.

$$
\begin{gathered}
\frac{\partial \mathrm{g}}{\partial \tau}=\beta_{0}\left[Y_{\mathrm{it}-1}\right]^{\beta_{1}+\beta_{2}-1}\left[\beta_{1}(\tau)^{\beta_{1}-1}(1-\tau)^{\beta_{2}}-\beta_{2}(\tau)^{\beta_{1}}(1-\tau)^{\beta_{2}-1}\right]=0 \\
\Rightarrow \beta_{1}(\tau)^{\beta_{1}-1}(1-\tau)^{\beta_{2}}=\beta_{2}(\tau)^{\beta_{1}}(1-\tau)^{\beta_{2}-1} \\
\Rightarrow \frac{\beta_{1}}{\tau}=\frac{\beta_{2}}{1-\tau}
\end{gathered}
$$

Hence, optimal tax rate is:

$$
\tau^{*}=\frac{\beta_{1}}{\beta_{1}+\beta_{2}}
$$

We assume constant returns to scale on production function, which allows us to write $\beta_{1}+\beta_{2}=1$. Hence, from equation (4), $\tau^{*}=\beta_{1}$ gives the optimal rate of taxation. To estimate the parameters, we simplify equation (3):

$$
\begin{aligned}
& 1+\mathrm{g}=\beta_{0}(\tau)^{\beta_{1}}(1-\tau)^{\beta_{2}} \\
& \left\{\text { since } \beta_{1}+\beta_{2}=1\right\}, \\
\Rightarrow & 1+\mathrm{g}=\beta_{0}(\tau)^{\beta_{1}(1-\tau)^{1-\beta_{1}}} \\
\Rightarrow & \frac{1+\mathrm{g}}{1-\tau}=\beta_{0}\left(\frac{\tau}{1-\tau}\right)^{\beta_{1}}
\end{aligned}
$$

Taking $\log$ to both sides, we get:

$$
\ln \left[\frac{1+\mathrm{g}}{1-\tau}\right]=\ln \beta_{0}+\beta_{1} \ln \left[\frac{\tau}{1-\tau}\right]
$$

Equation (5) is estimated through Fixed Effects Regression and value of $\beta_{1}$ is calculated.

\subsection{Alternative Model: The Quadratic Model}

Scully (1991) and others use the quadratic method with the assumption that tax revenue has a positive effect up to a certain level and negative effect after crossing that level. This means that tax revenue as measured in terms of GDP $(\tau)$ exhibits positive effect and square of tax $\left(\tau^{2}\right)$ exhibits a negative effect on growth. Now we define growth model in the form of linear and quadratic term of tax rate, with some control variables.

$$
\mathrm{g}_{\mathrm{it}}=\beta_{0}+\beta_{1} \tau_{\mathrm{it}}+\beta_{2} \tau^{2}{ }_{\mathrm{it}}+\beta_{3} \dot{K}_{\mathrm{it}}+\beta_{4} \mathrm{D}_{\mathrm{it}}+\beta_{5} \mathrm{Y}_{\mathrm{it}-1}+\mu_{\mathrm{it}}
$$

Where $g_{i t}$ is the growth rate, $\tau_{i t}$ is tax rate measured in terms of percentage of GDP, $K_{i t}$ is the growth in capital stock, $Y_{i t-1}$ is initial per capita GDP and $D_{i t}$ is the growth rate of the deficit of the country i at time t. The control variables have been used based on the large number of existing empirical literature. Initial per capita GDP measures the conditional convergence of the model, which implies that countries which have higher per capita GDP face low growth in comparison to those who have lower per capita GDP. Deficit is the fiscal variable which has direct impact on investment and growth, and the rate of capital growth is assumed to have a positive impact on growth.

The optimal solution from equation 6 is obtained by: $\tau^{*}=-\frac{\beta_{1}}{2 \beta_{2}}$

\section{The Data}

We use unbalanced panel data for 32 Asian countries from the period 1991 to 2012. The list of countries is shown in Appendix 1. Real GDP per capita growth rate is taken from World Development Indicator (WDI), World Bank. Tax rate is measured in terms of percentage of GDP and is drawn from the data set of Government Finance Statistics (GFS), International Monetary Fund (IMF). This tax revenue series belongs to the central government revenue. GDP per capita (US \$ Constant 2005), deficit and total investment are drawn from WDI data series. The deficit is defined as the net expenditure minus net revenue. Initial GDP per capita is the one year lag of the GDP per capita. The proxy for growth in capital stock is taken as investment. The average size of taxes measured as a percentage of GDP for the period 
1991-2012 is shown as below. ${ }^{2}$

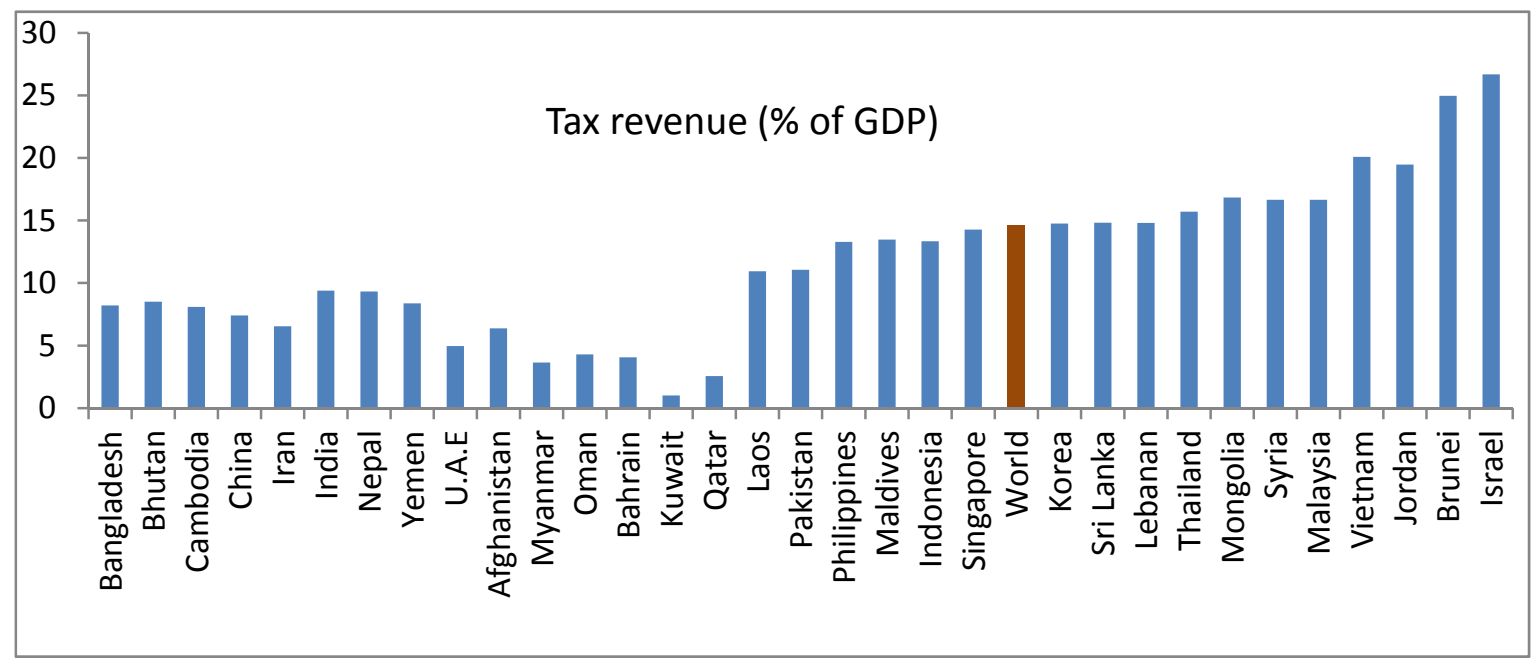

Figure 1. Status of Average Tax Performance in 32 Asian Countries in 1991-2012

Source: Author's calculation based on Government Finance Statistics (GFS), IMF

Figure 1 shows that the average size of tax burden in 15 Asian countries are less than 10 percent of GDP over the period 1991-2012. Developing countries such as Bangladesh, Bhutan, Cambodia, China, Iran, India, Nepal, Yemen, Afghanistan, and Myanmar belong to this category. Some countries belonging to Organization of the Petroleum Exporting Countries (OPEC) such as Kuwait, Qatar, United Arab Emirates (UAE) have quite low tax revenue. The average tax revenue of the sample countries over the period is 11.4 percent while that of the world is 14.1 percent of GDP. Only three countries comprising Vietnam, Brunei and Israel have tax revenue more than 20 percent of GDP.

If we observe the linear relationship between taxation and growth, we almost find positive relationship. Figure 2 shows the trend of average per capita growth rate and average tax revenue (percent of GDP). The upper line represents the tax burden ratio (percent of GDP) and the lower line represents the growth rate. The relationship tends to show the positive effect. The positive relationship is expected because Asian countries show quite low level of taxation which may not create burden like in highly taxed countries.

If we observe the quadratic line fit between tax level and growth, we find slightly inverse inverse U-shaped relationship. Figure 3 contains the tax level as measured in percentage of GDP in horizontal axis and per capita growth in vertical axis. The curve shows that up to some level (tentatively 15-20 percent of GDP), taxation shows positive result and after this size, it shows negative result.

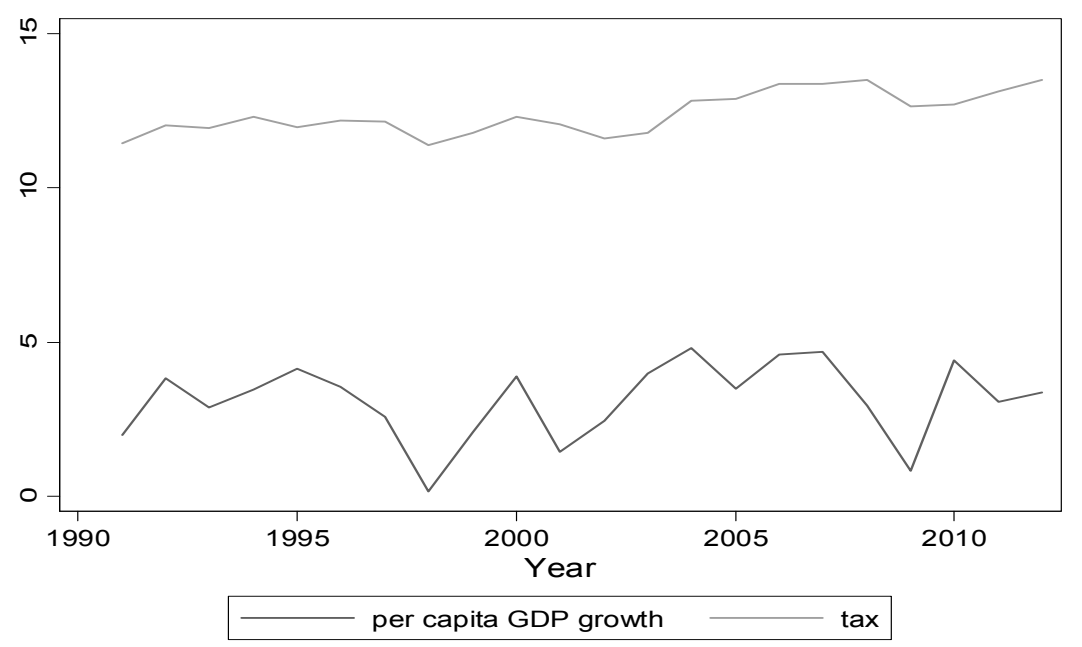

Figure 2. Linear Relationship between Taxes and Growth

Source: Author's calculation based on the data taken from World Development Indicator (WDI) and GFS

\footnotetext{
${ }^{2}$ The graphical explanation of the average tax performance and tax-growth relationship is based on the part of $\mathrm{PhD}$ thesis of the author.
} 


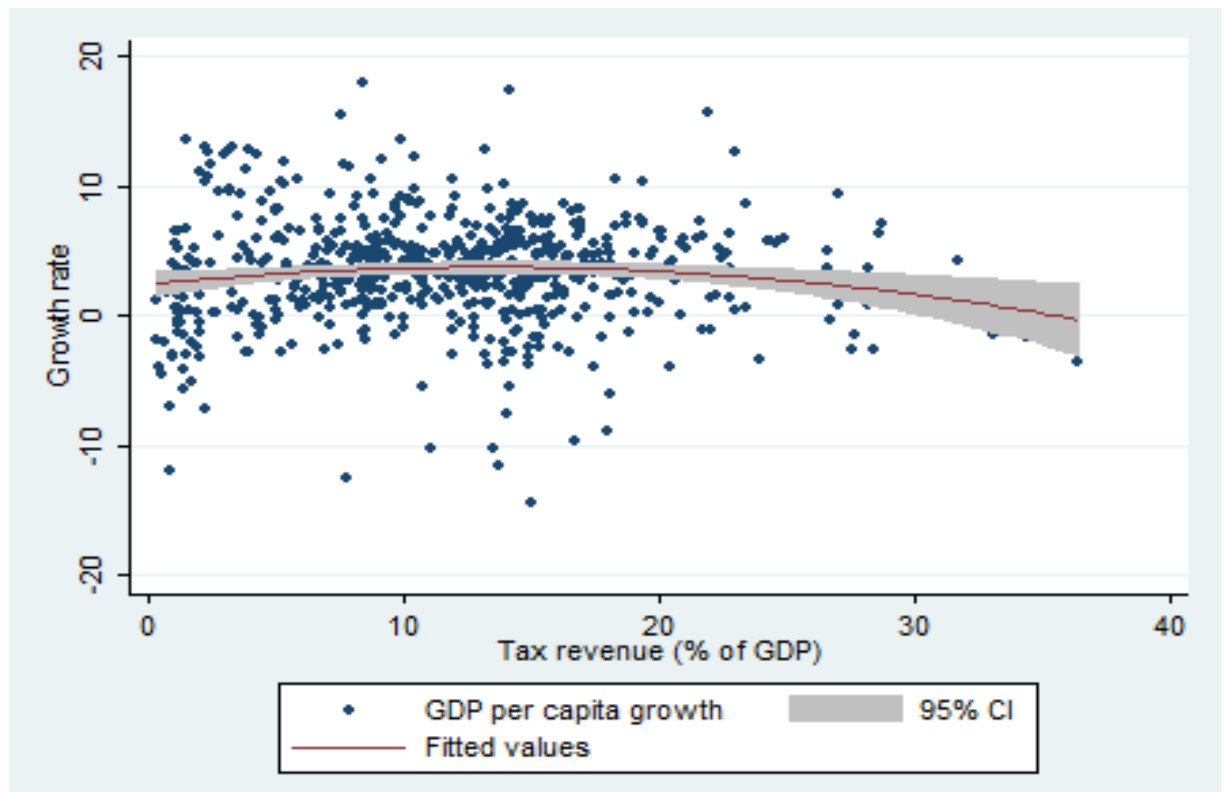

Figure 3. Quadratic Line fit between Tax Size and Growth

Source: Author's estimation based on the data taken from WDI and GFS.

\section{Empirical Result}

Table 1 shows the results obtained by estimating the Scully model (equation 5). Dependent variable includes the logarithm of $1+\mathrm{g}$ divided by $1-\tau$. Similarly, independent variable includes logarithm of $\tau$ divided by $1-\tau$. The equation has been estimated through simple fixed effects regression, with the assumption that some fixed factors such as the characteristics of the country affect the growth rate of the economy. The coefficient of the independent variable- $\beta_{1}$ is found to be 0.194 . This means the optimal tax rate for the growth maximization is 19.4 percent of GDP.

Table 1: Results for growth-maximizing taxation from full sample

Estimation Method: Fixed Effects Regression

Determinants Dependent variable : $\ln \left[\frac{1+\mathrm{g}}{1-\tau}\right]$

$$
\ln \left[\frac{\tau}{1-\tau}\right]
$$

Constant

No. of observation

601

$$
\mathrm{R}^{2}
$$

Note: $* * *, * *$, and $*$ indicate that variables are significant within the $1 \%, 5 \%$ and $10 \%$ levels, respectively. Standard errors in the parentheses.

Table 2 shows the regression results for GDP per capita growth obtained by using quadratic method. The size of tax revenue in GDP has positive effect, with the coefficient 0.43 , while square of tax revenue has a negative effect on growth, with the coefficient -0.012 . This means that tax revenue shows inverse U-shaped relationship on growth. As per expecatation, initial GDP per capita depicts a negative effect on growth, meaning that countries having higher GDP per capita in initial year face low growth in the coming year. The net growth in capital, which is referred to as investment, has a significant positive impact on growth and the deficit finance has a significant negative impact on growth. All variables are significant and in expected lines. The optimal taxation has been calculated in the table by using the formula as derived in equation 7 and found to be 18.12 of GDP. Up to this point, tax revenue shows a positive impact on growth and after this, growth rate starts to decline. 
Table 2. Regression results using Quadratic Model

\begin{tabular}{lc}
\hline & $\begin{array}{c}\text { Estimation Method: Fixed Effects Regression } \\
\text { Dependent Variable: Real per capita GDP growth }\end{array}$ \\
\hline Initial per capita GDP & $-0.0002^{* * *(0.0001)}$ \\
Tax & $0.435^{* *}(0.16)$ \\
Square of tax & $-0.012^{* *}(0.004)$ \\
Deficit & $-0.11^{* *}(0.03)$ \\
Capital growth & $0.12^{* * *}(0.035)$ \\
No. of observation & 515 \\
$\mathrm{R}^{2}$ & 0.23 \\
$\beta$ & $-\frac{0.435}{2(-0.012)}=18.12$
\end{tabular}

Note: $* * *, * *$, and $*$ indicate that variables are significant within the $1 \%, 5 \%$ and $10 \%$ levels, respectively. Standard errors in the parentheses.

To check how sensitive the results are, we further apply the test to the countries which do not belong to the members of OPEC countries. These countries, in general, have a quite low level of tax revenue, and it is supposed that this may mislead the result. But the results obtained from the non-OPEC countries are comparable to the whole sample. Table 3 shows that the optimal tax rate is 17.4 percent of GDP. This point is 2 percentage points less than the value obtained from the whole sample. This shows that this model is a little bit sensitive, however, the results are acceptable and comparable.

Table 4 shows the results from the quadratic model in non-OPEC countries. The variation of tax revenue in these countries is less than the whole sample. Regression results show that all variables are significant and also in expected lines. The coefficients of tax and square of tax are 0.471 and -0.013 , respectively. This model also verifies the existence of inverse U-shaped relationship between taxation and growth. The optimal value of tax revenue in terms of GDP is found to be 18.11 percent, which is nearly equal to the value obtained in the previous sample.

The finding observed from these tests is comparable with the Scully (1996) but not the same. Much empirical studies are based on linear models which may not show the positive impact of taxation on growth. But the countries where the tax revenue is in lower level, the increase in taxation may help reduce existing public debt stock and avoids its negative impact on growth. As many Asian countries have tax revenue less than 15 percent of GDP, Increase in tax size nearly up to 18 percent yields positive result on growth.

Table 3. Results for Optimal taxation from non-OPEC countries

\begin{tabular}{cc}
\hline & Estimation Method: Fixed Effects Regression \\
\cline { 2 - 3 } Determinants & Dependent variable $: \ln \left[\frac{1+\mathrm{g}}{1-\tau}\right]$ \\
\hline $\ln \left[\frac{\tau}{1-\tau}\right]$ & $0.174^{* * *}$ \\
Constant & $(0.08)$ \\
No. of observation & $2.00^{* * *}$ \\
$\mathrm{R}^{2}$ & $(0.21)$ \\
& 530 \\
\end{tabular}

Note: $* * *, * *$, and $*$ indicate that variables are significant within the $1 \%, 5 \%$ and $10 \%$ levels, respectively. Standard errors in the parentheses. 
Table 4. Regression results using Quadratic Model for non-OPEC countries

\begin{tabular}{lc}
\hline & \multicolumn{1}{c}{$\begin{array}{c}\text { Estimation Method: Fixed Effects Regression } \\
\text { Dependent Variable: Real per capita GDP growth }\end{array}$} \\
\hline Initial per capita GDP & $-0.0003 * * *(0.0001)$ \\
Tax & $0.471^{* *(0.177)}$ \\
Square of tax & $-0.013 * *(0.005)$ \\
Deficit & $-0.13 * *(0.04)$ \\
Capital growth & $0.11 * * *(0.02)$ \\
No. of observation & 453 \\
$\mathrm{R}^{2}$ & 0.24 \\
$\beta$ & $-\frac{0.471}{2(-0.013)}=18.11$
\end{tabular}

Note: $* * *, * *$, and $*$ indicate that variables are significant within the $1 \%, 5 \%$ and $10 \%$ levels, respectively. Standard errors in the parentheses.

The survey of empirical results which follow the Scully model indicates that the model seems to be more sensitive. Many economists criticize that the model is inappropriate to estimate the exact growth-maximizing tax rate (e.g. Kennedy, 2000; Hill, 2008). Kennedy (2000) has noted that growth rate is not solely determined by the taxation and if other factors are responsible to influence growth, the method gives spurious growth-maximizing tax rate. Another issue in the Scully model is the assumption of balanced budget. Many countries, in reality, have deficit budget, which may cause country specific variations in determining the optimal level of taxation. However, Scully method provides some insights to determine the optimal level of taxation to maximize growth.

\section{Conclusions}

This research examines the optimal level of taxation for growth maximization, using Scully (1996) and quadratic models in Asian countries for 1991-2012. The results provide a clear evidence of inverse U-shaped tax-growth relationship. The optimal tax rate to maximize growth for 32 Asian countries is around 18 percent of GDP. Scully model is a little bit sensitive, however, this model provides a tentative idea about the growth-maximizing level of taxation.

The notion of inverse U-shape relationship between taxation and growth is likely to be more convincing and practicable idea. If the government is unable to collect sufficient tax revenue, the role of fiscal policy will be limited, and this may cause distortions in the economy, with the limited output growth. Similarly, the higher taxation, in one hand, causes excess burden to the private sector and reduces the investment activities. The transfer of resources from the productive private sector to less efficient government sector, on the other hand, may reduce the net productivity of the capital. This means that a certain amount of tax revenue, but not more than the taxation capacity of the country, is beneficial for the economy. Hence, the finding of this research has an important policy implication.

The level of tax revenue in Asia is comparatively lower than other regions of the world. The average tax revenue in the last two decades is around 11.4 percent of GDP and the optimal tax revenue to maximize the growth rate is around 7 percentage points higher than this. More than 25 countries out of 32 have average tax revenues less than 18 percent of GDP in 2012. Over the recent two decades, there has been no significant improvement in tax revenues. This scenario shows that increases in tax revenues up to 18 percent of GDP do not hamper growth in Asian countries.

Growth doesn't depend solely on taxation. Many macroeconomic and socio-political factors determine the aggregate growth. Hence, this study provides a tentative framework on maintaining the level of taxation in GDP for growth maximization.

\section{Acknowledgements}

The author is grateful to the Professors Yoichi Matsubayashi and Tomomi Miyazaki for their invaluable suggestions on an earlier version of this manuscript. Similarly, the Author would like to thank the editor and anonymous referees for their helpful comments.

\section{References}

Abdullaev, B., \& Konya, L. (2014). Growth-maximizing Tax Rate for Uzbekistan. Applied Econometrics and International Development, 14(1).

Armey, R. K. (1995). The Freedom Revolution: The New Republican House Majority Leader Tells Why Big Government 
Failed, Why Freedom Works, and How We Will Rebuild America, ,Washington, D.C.; Regnery Publishing Inc..

Barro, R. J. (1990). Government Spending in a Simple Model of Endogenous Growth. Journal of Political Economy, 98 , S103-S125. https://doi.org/10.1086/261726

Chao, J., \& Grubel, H. (1998). Optimal Levels of Spending and Taxation in Canada. The Fraser Institute, Vancouver.

Davidsson, M. (2012). Optimal Growth Taxation. Research in World Economy, 3(1), 35-44. https://doi.org/10.5430/rwe.v3n1p35

Easterly, W., \& Rebelo, S. (1993). Fiscal Policy and Economic Growth: An Empirical Investigation. National Bureau of Economic Research, Working Paper, 4223. https://doi.org/10.3386/w4499

Gale, W. G., Krupkin, A., \& Rueben, K. (2015). The Relationship between Taxes and Growth at the State Level: New Evidence. National Tax Journal, 68(4), 919-942. https://doi.org/10.17310/ntj.2015.4.02

Hill, R. (2008). Optimal Taxation and Economic Growth: A comment. Public Choice, 134, 419-427. https://doi.org/10.1007/s11127-007-9235-0

Husnain, M. I., Haider, A., \& Salman, A. (2015). Determining the Optimal Level of Taxes in South Asia: An Unbalanced Budget Approach. The Empirical Economics Letter, 14(8), 809-815.

Jones, L. E., Manuelli, R. E., \& Rosi, P. E. (1993). Optimal Taxation in Models of Endogenous Growth. Journal of Political Economy, 101(3), 485-517.https://doi.org/10.1086/261884

Keho, Y. (2010). Estimating the Growth Maximizing Tax Rate for Cote d'Ivorie: Evidence and implications. Journal of Economics and International Finance, 2(9), 164-174.

Kennedy, P. E. (2000). On Measuring the Growth Maximizing Tax Rate. Pacific Economic Review, 5(1), 89-91. https://doi.org/10.1111/1468-0106.00090

King R. G., \& Rebelo, S. (1990). Public Policy and Economic Growth: Developing Neoclassical Implications. Journal of Political Economy, 98(5), S126-S150. https://doi.org/10.1086/261727

Mankiw, N. G., Weinzierl, M.,\& Yagan, D. (2009). Optimal taxation in theory and practice. Journal of Economic Perspectives,23(4), 147-174. https://doi.org/10.1257/jep.23.4.147

McBride, W. (2012). What Is the Evidence on Taxes and Growth? Tax Foundation, Special Report no. 207.

Rahn, R., \& Fox, H. (1996). What Is the Optimum Size of Government, Vernon K. Krieble Foundation.

Saibu, O. M. (2015). Optimal Tax Rate and Economic Growth. Evidence from Nigeria and South Africa, EuroEconomica, 1(34).

Scully, G. W. (1991). Tax Rates, Tax Revenues and Economic Growth. National Center for Policy Analysis, Policy Report,159.

Scully, G. W. (1995). The "Growth Tax" in the United States. Public Choice, 85(1/2), 71-80. https://doi.org/10.1007/BF01047902

Scully, G. W. (1996). Taxation and Economic Growth in New Zealand. Pacific Economic Reveiew, 1(2), 279-177. https://doi.org/10.1111/j.1468-0106.1996.tb00182.x

Scully, G. W. (2003). Optimal Taxation, Economic Growth and Income Inequality, Public Choice, 115, 299-312. https://doi.org/10.1023/A:1024223916710

Scully, G. W. (2006). Taxation and Economic Growth., National Center for Policy Analysis,Policy Report, 292.

Appendix 1. Sample countries (32 Asian Countries)

\begin{tabular}{llll}
\hline Non-OPEC countries (27) & & OPEC countries (5) \\
\hline Afghanistan. Bangladesh, Bhutan, India, Maldives, Nepal, & & Saudi Arabia*, Iran, Iraq*, \\
Pakistan, Sri Lanka, Cambodia, Malaysia, Philippines, & & Indonesia, Kuwait, Qatar, UAE \\
Laos, Vietnam, Myanmar, Thailand, Mongolia, China, & & \\
Israel, Brunei, Singapore, South Korea, Oman, Jordan, & \\
Syria, Lebanon, Yemen, Bahrain & &
\end{tabular}

*Indicates that tax data are not available. 
Appendix 2. A brief summary of literature review

\begin{tabular}{|c|c|c|c|}
\hline Researchers & Sampling country/ period & Conclusion & Method \\
\hline Keho (2010) & Cote d’Ivorie (1960 2006) & $\begin{array}{l}\text { Optimal tax rate } 22.1 \sim 22.3 \% \text { of } \\
\text { GDP }\end{array}$ & $\begin{array}{l}\text { Scully and Quadratic } \\
\text { models }\end{array}$ \\
\hline Saibu (2015) & South Africa and Nigeria & $\begin{array}{l}\text { South Africa-15\%, Nigeria-30\% of } \\
\text { GDP }\end{array}$ & $\begin{array}{l}\text { Scully and } \\
\text { Quadratic models }\end{array}$ \\
\hline Chao and Grubel (1998) & Canada (1926 1996) & $34 \%$. Of GDP & Scully model \\
\hline $\begin{array}{l}\text { Abdullaev and Konya } \\
\text { (2014) }\end{array}$ & Uzbekistan (1996 2011) & $\begin{array}{l}22 \text { and } 31.2 \% \text { of GDP for two } \\
\text { different periods }\end{array}$ & Scully model \\
\hline Davidsson (2012) & $\begin{array}{l}\text { Randomly selected } 12 \text { countries } \\
\text { (1982 2012) }\end{array}$ & $11.1 \%$ of GDP & Based on Scully model \\
\hline $\begin{array}{l}\text { Husnain, Haider and } \\
\text { Salman (2015) }\end{array}$ & $\begin{array}{l}4 \text { South Asian countries } \\
(1975 \sim 2012)\end{array}$ & $13.7 \%$ of GDP & Scully model \\
\hline Scully (1991) & 103 countries $(1960 \sim 1980)$ & $\begin{array}{l}19.3 \% \text { of GDP ( } 43.2 \% \text { to maximize } \\
\text { revenue) }\end{array}$ & Quadratic model \\
\hline Scully (1995) & USA (1949 1989) & $21.5-22.9 \%$ of GNP & $\begin{array}{l}\text { Scully developed his } \\
\text { own model }\end{array}$ \\
\hline Scully (1996) & New Zealand (1927 1994) & $19.7-20.02 \%$ of GDP & Scully model \\
\hline Scully (2003) & USA (1960 1990) & 19.3 and $25.1 \%$ of GDP & Scully and Barro models \\
\hline Scully (2006) & USA (1929 2004) & $23 \%$ of GDP & Scully model \\
\hline
\end{tabular}

\section{Copyrights}

Copyright for this article is retained by the author(s), with first publication rights granted to the journal.

This is an open-access article distributed under the terms and conditions of the Creative Commons Attribution license which permits unrestricted use, distribution, and reproduction in any medium, provided the original work is properly cited. 